Egypt. Acad. J. biolog. Sci., 1 (1): 59 - 68 (2009)

Email: egyptianacademic@yahoo.com

Received: 17/11/2009
F. Toxicology \& pest control

ISSN: 2090 - 0791

www.eajbs.eg.net

\title{
Biochemical changes of the Chitin-synthesis inhibitor, Hexaflumuron (Consult) compound on the desert locust, Schistocerca gregaria (Forskal)
}

\author{
Reda, F.A. Bakr ${ }^{1}$; Mona, I. Mohammed ${ }^{1}$; Abd Elazeem, M. El-Gammal. ${ }^{2}$ and \\ Noura, M. Mahdy ${ }^{2}$ \\ 1- Department of Entomology - Faculty of Science, Ain-Shams University \\ 2-Plant Protection Research Institute, Agric. Res. Center
}

\begin{abstract}
Feeding application of different concentrations of Consult on one day old and six day old of the $5^{\text {th }}$ nymphal instar of the desert locust, Schistocerca gregaria (Forskal) showed reduction of total protein of haemolymph in nymphs and adults, also reduction in total ovary and testis protein of adults were observed.
\end{abstract}

Key words: Biochemical, Hexaflumuron, Schistocerca gregaria

\section{INTRODUCTION}

The desert locust, Schistocerca gregaria (Forskal) is one of the most economic pests causing severe damage to crops, which consider the main food for human and animals. So, it seemed necessary to develop an effective preventive control strategy depends upon the early warning to suppress this multiplication and prevent the outbreak of the mobile swarms by an effective control tool against its nymphal instars.

Plagues of the Desert Locust (Schistocerca gregaria) have threatened agricultural production in Africa, the Middle East, and Asia for centuries. The livelihood of at least one-tenth of the world's human population can be affected by this voracious insect. The Desert Locust is potentially the most dangerous of the locust pests because of the ability of swarms to fly rapidly across great distances. It has two to five generations per year

The 2004 desert locust outbreak has caused significant crop losses in West Africa and had a negative impact on food security in the region. In the last few years, scientists directed their efforts towards the control of insects by the use of insect growth regulators to avoid the hazards of insecticides
IGRs are diverse groups of chemical compounds that are highly active against immature stage of insects and have a good margin of safety to most non-target biota including invertebrates, fishes, birds and other wild life, they are also safe to man and domestic animals, they will play an important role in vector control programs in the future (Mulla, 1995; Bakr et al. 1984 and 1989).

The main types of insect growth regulators used commercially are juvenile hormone analogues and chitin synthesis inhibitors (Parrella and Murphy, 1998).

\section{MATERIALS AND METHODS}

1. Maintenance of the culture:

1.1. Origin of stock culture and rearing in the laboratory:

The stock colony of Schistocerca gregaria was maintained for several years at the Locust research Division, Plant Protection Research Institute, Agricultural Research Center, Dokki, Giza. The insects were reared and handled under the following technique described by Abbassi et al. 2003 and Bakr et al. 2008.

Leaves of leguminous plant, Medicago sativa were daily placed as feeding material. The cages were incubated in a constant room temperature $\left(32 \pm 2^{\circ} \mathrm{C}\right)$ and $(30-50 \% \mathrm{RH})$. 


\subsection{Experimental insects:}

The experimental nymphs were segregated from the gregarious stock colony at the beginning of the first nymphal instar and held up in cages $(30 \times 30 \times 30 \mathrm{~cm})$ in diameter. The cages were a wooden farmed equipped with zinc bottom covered by thin layer of sand, glass covered sides and a wiregauze top provided with a little door. All cages were incubated at $\left(32 \pm 2^{\circ} \mathrm{C}\right)$ and (30-50\% RH). Unconsumed food, dead locusts and faces were removed daily.

The whole cage was thoroughly washed and effectively sterilized with an antiseptic agent every (4-6 weeks) or when ever it becomes empty or at the end of any experiment.

\section{Insecticides used:}

Hexaflumuron (10\% EC) (Chitinsynthesis inhibitor):

Consult (Hexaflumuron), [N 3,5-dichloro-4-(1,1,2,2-tetrafluroethoxy phenyl-amino carbonyl) -2,6difluroben- zamide].

3. Treatment of experimental insects:

Both sexes of nymphs of oneday old and 6-day old of the $5^{\text {th }}$ nymphal instar of $S$. gregaria during synthesis and deposition of the newly adult cuticle (Taha and El-Gammal 1990) were treated by feeding technique with Consult as the following:

Leaves of $M$. sativa were dipped in 50, 75 and $100 \mathrm{ppm}$ of Consult for two minutes. Then leaves were air dried before being offered to the nymphs for feeding on it. Three replicates of 20 nymphs were subjected to each of the treated leaves.

After feeding for 24 hours on the treated leaves, the alive nymphs were transferred onto untreated leaves and left to feed for 24 hours after that mortality counts or malformed individuals were recorded.

\section{Biochemical studies:}

\subsection{Samples collection:}

Samples were collected from males and females of $5^{\text {th }}$ nymphal instar of $S$. gregaria as well as adult males and females according to Sorge et al. (2000).

\subsubsection{Haemolymph collection and preparation:}

Haemolymph was collected from nymphs and adults with a calibrated capillaries through a puncture in the neck membrane and gently pressing the insect abdomen. The haemolymph was allowed to flow into $1.5 \mathrm{ml}$ ice cold micro centrifuge tubes that contained few crystals of phenylthiourea. The haemolymph was centrifuged at $10000 \mathrm{rpm}$ for 5 minutes at $4^{\circ} \mathrm{C}$.

4.1.2. Tissue collection and preparation: Tests and ovary were dissected from adult insect, and homogenized in distilled water for 3 minutes, homogenates were centrifuged at 8000 $\mathrm{rpm}$ for 5 minutes at $-2^{\circ} \mathrm{C}$. The supernatant can be used directly or stored at $-5^{\circ} \mathrm{C}$ until use for biochemical determination. Care was taken to remove all the loose perivisceral fat tissue. Tissues were frozen in order to disrupt membrane enclosed protein granules.

4.2. Quantitative determination of total proteins:

Total proteins of the haemolymph were estimated according to the method described by Bradford (1976). This method is based on the observation that Coomassi Brilliant Blue G-250 exists in two different colour forms, red and blue. The red colour is converted to the blue colour upon binding of the dye to protein; this binding causes a shift in maximum absorption of the dye from 465 to 595 $\mathrm{nm}$. The intensity of the colour was measured at $595 \mathrm{~nm}$. 
4.2.1. Preparation of protein reagent:

Coomassi Brilliant Blue (N) G$250(100 \mathrm{mg})$ was dissolved in $50 \mathrm{ml}$ at concentration $95 \%$ ethanol. To this solution, $100 \mathrm{ml}$ at concentration $85 \%$ (w/v) Phosphoric acid was added. The resulting solution was diluted to a final volume of one liter.

\subsubsection{Preparation of standard protein solution:}

Bovine Serum Albumin solution (BSA), $0.8 \mathrm{mg} / \mathrm{ml}$ was prepared by carefully dissolving $80 \mathrm{mg}$ of (BSA) in $100 \mathrm{ml}$ of distilled water, then dispensed into $10 \mathrm{ml}$ aliquots and stored in the deep freezer at $-18^{\circ} \mathrm{C}$ until required. Once a tube of Bovine Serum Albumin solution was thawed for use, any excess remained was discarded.

\subsubsection{Procedure:}

Sample solution $50 \mu \mathrm{l}$ for preparation of standard curve $50 \mu \mathrm{l}$ of serial concentration containing 50to $100 \mu \mathrm{g}$ bovine serum albumin were pipettde into test tubes. The volume in the test tube was adjusted to $0.1 \mathrm{ml}$ with phosphate buffer $\mathrm{pH}=6.65 \mathrm{ml}$ of protein reagent were added to the test tube and the content were mixed either by inversion or vortexing. The absorbance at $595 \mathrm{~nm}$ was measured after 2 minutes and before one $\mathrm{hr}$ against a reagent blank prepared from $0.1 \mathrm{ml}$ of phosphate buffer $\mathrm{pH}=6.6$ and $5 \mathrm{ml}$ of protein reagent.

\section{Calculations and data analysis:}

Statistical analysis of results was statistically analyzed by analysis of variance (ANOVA) and the means were compared by L.S.D. test at 0.05 level, using SAS program (SAS, 1988).

\section{Biochemical effects:}

\section{RESULTS}

1. Effect of Consult on protein levels in haemolymph of the $5^{\text {th }}$ nymphal instar of $S$. gregaria:

Data in Table (1) and Figs (1\&2) showed that, the levels of haemolymph protein content were significantly and negatively deceased after 24 and 168 hrs when the female and male of the $5^{\text {th }}$ nymphal instar were treated during one day old with different concentrations of Consult compound. Whereas, the levels of haemolymph protein content decreased after $24 \mathrm{hrs}$ of treatment during 6-day old at different concentrations; 50, 75 and 100 ppm of Consult.

Table (1): Metabolic effect of Consult on haemolymph protein content of treated one and six day old male and female $5^{\text {th }}$ nymphs of the desert locust, Schistocerca gregaria.

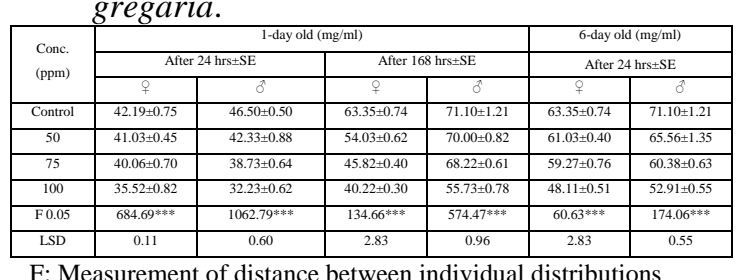

F: Measurement of distance between individual distributions LSD: Least Significant Deference

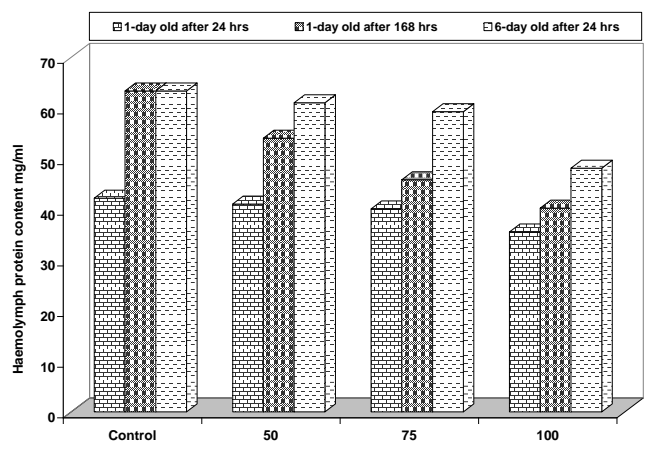

Fig. (1):Metabolic effect of Consult on haemolymph protein content of treated one and six day old female $5^{\text {th }}$ nymphs of the desert locust, Schistocerca gregaria.

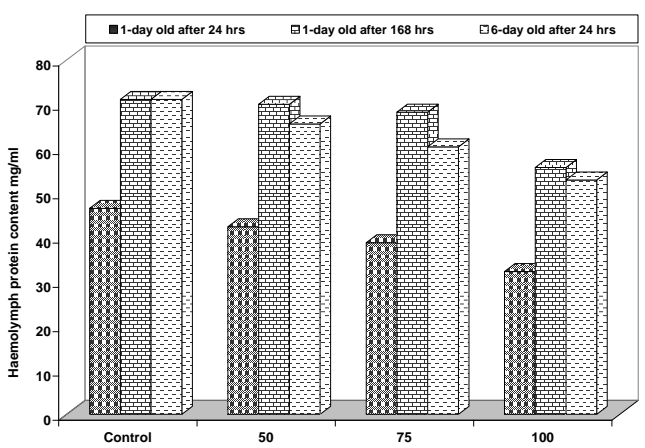

Fig.2: Metabolic effect of Consult on haemolymph protein content of treated one and six day old male 5th nymphs of the desert locust, Schistocerca gregaria. 
Haemolymph samples were collected from untreated and treated nymphs, showed quantitative differences in protein content.

During one day old treatment, the haemolymph protein levels significantly decreased in treated female nymphs after $24 \mathrm{hrs}$ of treatment, these levels were 41.03, 40.06 and $35.52 \mathrm{mg} / \mathrm{ml}$ at different concentrations; 50, 75 and $100 \mathrm{ppm}$, respectively compared with 42.19 $\mathrm{mg} / \mathrm{ml}$ of untreated females.

Also, haemolymph protein levels deceased in treated females after $168 \mathrm{hrs}$ of treatment, these levels were $54.03,45.82$ and $40.22 \mathrm{mg} / \mathrm{ml}$ at different concentrations; 50, 75 and 100 ppm, respectively compared with $63.35 \mathrm{mg} / \mathrm{ml}$ of normal females, but these results indicated that the haemolymph protein levels increase after $168 \mathrm{hrs}$.

In case of treatment during sixday old, the haemolymph protein levels in treated females were significantly decreased but less than the decreasing which resulted after 168 hrs in treated the $5^{\text {th }}$ nymphal instar during one-day old, which were 61.03, 59.22 and $48.11 \mathrm{mg} / \mathrm{ml}$, respectively with different concentrations; 50, 75 and $100 \mathrm{ppm}$, respectively compared with $63.35 \mathrm{mg} / \mathrm{ml}$ of untreated females.

The haemolymph protein levels of treated male nymphs, which were treated during one-day old after $24 \mathrm{hrs}$ reached $42.33,38.73$ and $32.23 \mathrm{mg} / \mathrm{ml}$, respectively with different concentrations; 50, 75 and $100 \mathrm{ppm}$, respectively compared with $46.50 \mathrm{mg} / \mathrm{ml}$ of untreated males.

The haemolymph protein levels increased after $168 \mathrm{hrs}$ more than after $24 \mathrm{hrs}$ of treatment but these levels decreased with increasing Consult concentrations showed 70.00, 68.22 and $55.73 \mathrm{mg} / \mathrm{ml}$ in the same previous mentioned concentrations, respectively compared with $71.10 \mathrm{mg} / \mathrm{ml}$ of untreated males.

During six-day old treatments, the haemolymph protein levels after 24 hrs of treated males gave $65.56,60.38$ and $52.91 \mathrm{mg} / \mathrm{ml}$ with different concentrations; 50, 75 and $100 \mathrm{ppm}$, respectively compared with 71.10 $\mathrm{mg} / \mathrm{ml}$ of untreated.

The obtained results showed that, the haemolymph protein levels in treated males after $168 \mathrm{hrs}$ of treatment during one-day old increased than which produced from treatment during six-day old.

Statistical analysis in (Table 1) show highly significant differences between haemolymph protein content of males and females, which obtained from the $5^{\text {th }}$ nymphs of Schistocerca gregaria during one day old after 24 hrs from treatment with Consult compound $(\mathrm{F}=684.69$ and $1062.79 \&$ $\mathrm{LSD}=0.11$ and 0.60 ), respectively.

Also, show highly significant differences between haemolymph protein content of males and females, which obtained from the $5^{\text {th }}$ nymphs of Schistocerca gregaria during one day old after $168 \mathrm{hrs}$ from treatment with Consult compound $(\mathrm{F}=134.66$ and 574.47\& LSD $=2.83$ and 0.96), respectively.

In addition, it show highly significant differences between haemolymph protein content of males and females, which obtained from the $5^{\text {th }}$ nymphs of Schistocerca gregaria during six day old after $24 \mathrm{hrs}$ from treatment with Consult compound $(\mathrm{F}=$ 60.63 and $174.06 \&$ LSD $=2.83$ and $0.55)$, respectively.

\section{Effect of Consult on protein levels} in haemolymph of $S$. gregaria adults:

Data in Table (2) and Figs (3\&4) showed that, the levels of haemolymph protein content when treatment during one day old of the $5^{\text {th }}$ nymphal instars, the haemolymph protein levels in adult females after the 
$7^{\text {th }}$ day reached $41.13,36.63$ and 26.46 $\mathrm{mg} / \mathrm{ml}$ at different concentrations 50 , 75 and 100 ppm, respectively compared with $42.56 \mathrm{mg} / \mathrm{ml}$ in control.

Table (2): Metabolic effect of Consult on haemolymph protein content of male and female moulted adult of one and six day old treated male and female of the $5^{\text {th }}$ nymphs of Schistocerca gregaria after 7 and 10 days.

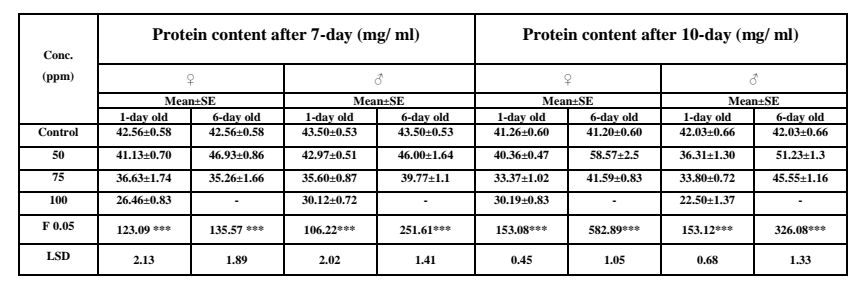

F: Measurement of distance between individual distributions LSD: Least Significant Deference

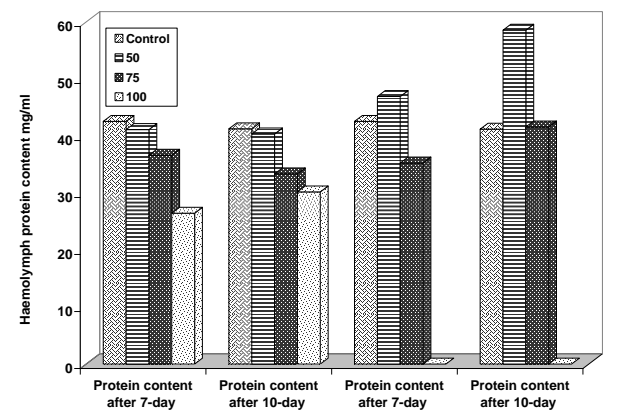

Fig. (3): Metabolic effect of Consult on haemolymph protein content of female adults of treated one and six day old 5th nymphs of Schistocerca gregaria after 7 and 10 days.

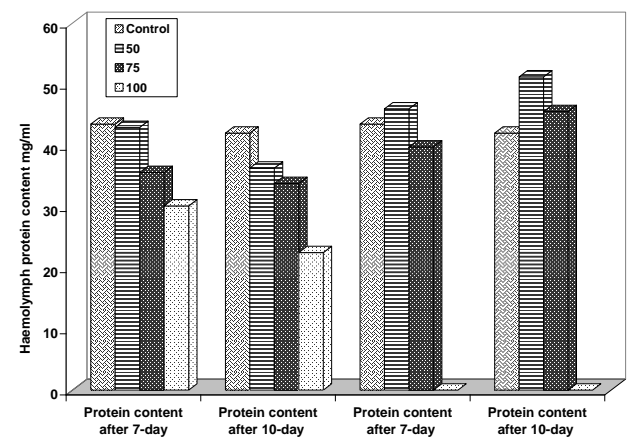

Fig. (4):Metabolic effect of Consult on haemolymph protein content of male adults of treated one and six day old 5th nymphs of Schistocerca gregaria after 7 and 10 days.

On the other hand, protein levels after the $10^{\text {th }}$ day significantly decreased in treated females; were $40.36,33.37$ and $30.19 \mathrm{mg} / \mathrm{ml}$ with the same above mentioned Consult concentrations compared with $41.26 \mathrm{mg} / \mathrm{ml}$ of untreated female adults.

In the treated male adults, haemolymph protein levels were
42.97, 35.60 and $30.12 \mathrm{mg} / \mathrm{ml}$ after the $7^{\text {th }}$ day compared with $43.50 \mathrm{mg} / \mathrm{ml}$ in control, whereas $36.31,33.80$ and $22.50 \mathrm{mg} / \mathrm{ml}$ after the $10^{\text {th }}$ day at different concentrations 50, 75 and 100 ppm, respectively compared with $42.03 \mathrm{mg} / \mathrm{ml}$ of adult control.

In treatments during six day old of the $5^{\text {th }}$ nymphal instars, the haemolymph protein levels in adult females after the $7^{\text {th }}$ day reached 46.93 and $35.26 \mathrm{mg} / \mathrm{ml}$ at different concentrations 50 and $75 \mathrm{ppm}$, respectively compared with 42.56 $\mathrm{mg} / \mathrm{ml}$ in untreated adult females.

After the $10^{\text {th }}$ day, the total haemolymph protein levels were 58.57 and $41.59 \mathrm{mg} / \mathrm{ml}$ at the same concentrations compared with 41.26 $\mathrm{mg} / \mathrm{ml}$ in control.

In treated male adults, the total haemolymph protein levels after the $7^{\text {th }}$ day were 46.00 and $39.77 \mathrm{mg} / \mathrm{ml}$ at same concentrations compared with 43.50 $\mathrm{mg} / \mathrm{ml}$ in untreated adult males, while the total haemolymph protein levels during the $10^{\text {th }}$ day were 51.23 and $45.55 \mathrm{mg} / \mathrm{ml}$ at same concentrations compared with 42.03 $\mathrm{mg} / \mathrm{ml}$ in control.

These results of six day old treatment showed that increasing the total haemolymph protein contents after the $7^{\text {th }}$ and the $10^{\text {th }}$ day with $50 \mathrm{ppm}$ comparing with control, then reduced again in the other concentration for male and female also found increasing in the total haemolymph protein contents during the $10^{\text {th }}$ day than in the $7^{\text {th }}$ day rather than adults' control.

Statistical analysis in (Table 2) show highly significant differences between haemolymph protein content after ten day of adult males females, which produced from the treated $5^{\text {th }}$ nymphs of $S$. gregaria with Consult compound $(\mathrm{F}=123.09$ and $135.57 \&$ LSD $=2.13$ and 1.89 for females), while in males $\mathrm{F}=106.22$ and 251.61 $\& \mathrm{LSD}=2.02$ and 1.41 ), respectively. 
Also, it show highly significant differences between haemolymph protein content of adult males and females after the $10^{\text {th }}$ day, which produced from the treated $5^{\text {th }}$ nymphs of $S$. gregaria with Consult compound $(\mathrm{F}=153.08$ and $582.89 \& \mathrm{LSD}=$ 0.45 and 1.05 for females), while in males $\mathrm{F}=$ 153.12 and $326.08 \&$ LSD $=0.68$ and 1.33 ), respectively

3. Effect of Consult on protein levels in ovaries and testes of $S$. gregaria adults:

Data in Table (3) and Figs (5\&6) showed that, the protein content were significantly deceased in treated adult females and males of the treated $5^{\text {th }}$ nymphs during one and six day old when increasing Consult concentrations, these reduction in levels of ovaries and testes protein was recorded after 10 days.

Table (3): Metabolic effect of Consult on ovary and testis protein content of moulted adult of one and six day old treated male and female $5^{\text {th }}$ nymphs of Schistocerca gregaria after 10 days.

\begin{tabular}{|c|c|c|c|c|}
\hline \multirow{2}{*}{ Conc. (ppm) } & \multicolumn{3}{|c|}{ Protein content after 10 days (mg/g. tissue) } \\
\cline { 2 - 5 } & \multicolumn{2}{|c|}{ ( (ovary) } & \multicolumn{2}{c|}{ (testis) } \\
\cline { 2 - 5 } & $\mathbf{1 - d a y ~ o l d ~}$ & $\mathbf{6 - d a y ~ o l d ~}$ & $\mathbf{1 - d a y ~ o l d ~}$ & $\mathbf{6 - d a y ~ o l d ~}$ \\
\hline Control & $81.8 \pm 1.3$ & $81.8 \pm 1.3$ & $87.5 \pm 1.4$ & $87.5 \pm 1.1$ \\
\hline $\mathbf{5 0}$ & $75.0 \pm 1.9$ & $69.0 \pm 1.5$ & $63.9 \pm 2.0$ & $53.9 \pm 1.3$ \\
\hline $\mathbf{7 5}$ & $36.35 \pm 1.7$ & $11.01 \pm 1.0$ & $53.0 \pm 1.0$ & $30.7 \pm 1.5$ \\
\hline $\mathbf{1 0 0}$ & $11.9 \pm 0.9$ & - & $28.9 \pm 1.0$ & - \\
\hline $\mathbf{F ~ 0 . 0 5}$ & $\mathbf{6 2 4 . 3 8 * * *}$ & $\mathbf{6 0 0 . 2 5 * * *}$ & $\mathbf{8 6 0 . 2 7 * * *}$ & $\mathbf{6 2 9 . 6 7 * * *}$ \\
\hline LSD & $\mathbf{1 . 3 6}$ & $\mathbf{1 . 7 2}$ & $\mathbf{2 . 7 1}$ & $\mathbf{1 . 5 2}$ \\
\hline
\end{tabular}

F: Measurement of distance between individual distributions LSD: Least Significant Deference

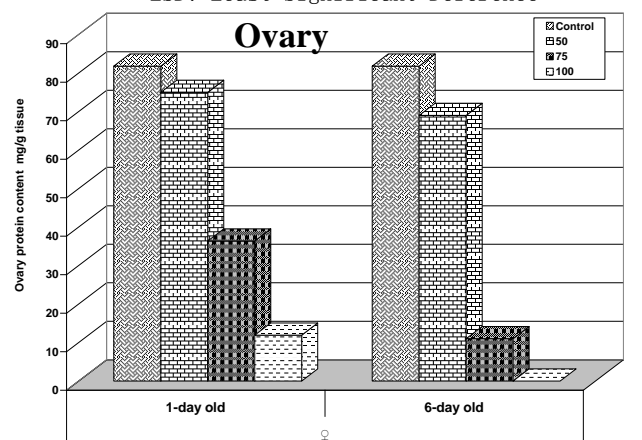

Fig. 5: Metabolic effect of Consult on ovary protein content of moulted adult of treated one and six day old female 5th nymphs of Schistocerca gregaria after 10 days.

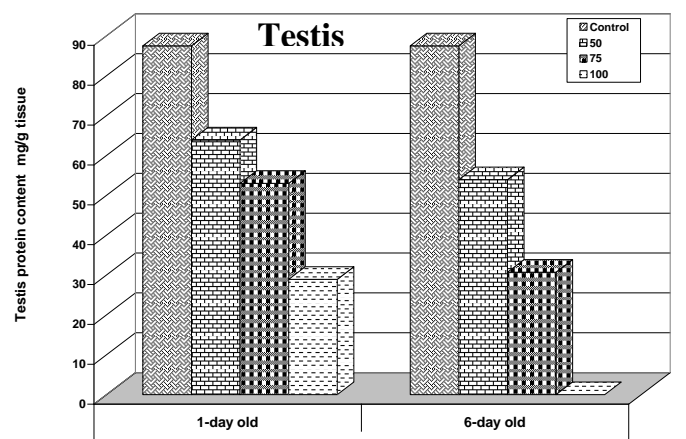

Fig. (6):Metabolic effect of Consult on testis protein content of moulted adult of treated one and six day old male 5th nymphs of Schistocerca gregaria after 10 days.
In treated ovary of one day old treatments, the protein levels reached 75.0, 36.35 and $11.90 \mathrm{mg} / \mathrm{g}$ tissue at different concentrations; 50, 75 and $100 \mathrm{ppm}$ of Consult, respectively compared with 81.80 $\mathrm{mg} / \mathrm{g}$ tissue in untreated.

In the adult male, the testis protein levels reached 63.90, 53.00 and 28.90 $\mathrm{mg} / \mathrm{g}$ tissue at above mentioned concentrations of Consult compared with $87.50 \mathrm{mg} / \mathrm{g}$ tissue in untreated adult males.

During six day old treatment of the $5^{\text {th }}$ nymphal instars, the ovaries and testes protein levels in treated female and male adults were obtained in 50 and 75 ppm only due to failure of ecdysis in the $5^{\text {th }}$ nymphs to adults; which reached to $100 \%$ in 100 ppm concentration.

In the treated adult female, ovary protein levels reached 69.0 and $11.0 \mathrm{mg} / \mathrm{g}$ tissue compared to $81.8 \mathrm{mg} / \mathrm{gm}$ tissue in normal females. Whereas, in the treated adult male, the protein levels of testes were 53.9 and $30.7 \mathrm{mg} / \mathrm{g}$ tissue at above mentioned concentrations of Consult compared with $87.50 \mathrm{mg} / \mathrm{g}$ tissue in untreated adult males.

Statistical analysis in (Table 3) show highly significant differences between ovary and testis protein content after 10 days of moulted of treated adult males and females which produced from the treated $5^{\text {th }}$ nymphs of $S$. gregaria during one day old treatment with Consult $(\mathrm{F}=624.38$ and $860.27 \& \mathrm{LSD}=1.36$ and 2.71 for females and males), while of six day old treatment $(F=600.25$ and 629.67 $\& \mathrm{LSD}=1.72$ and 1.5 ), respectively.

\section{Biochemical effects:}

\section{DISCUSSION}

Quantitative assays of protein in the haemolymph and reproductive organs are of considerable importance for the understanding of the different physiological process associated with reproduction. In insects, changes in proteins are prominent during stages undergoing marked development and tissues differentiation such as during metamorphosis (Eassa et al., $1971 \mathrm{Al}$; rubeai and Gorell, 1982; Bakr et al. 2007 and 2008) and sexual maturity of the reproductive organs (Engelmann, 1970). 


\section{Total protein in haemolymph: \\ 1.1. In nymphs:}

The obtained data indicated that, the metabolic actions of chitin synthesis inhibitor (Consult) on total haemolymph protein of the $5^{\text {th }}$ nymphal instar were carried out after 24 and 168 hours of the treated one day old $5^{\text {th }}$ nymphal instar and after 24 hours of treated six day old $5^{\text {th }}$ nymphal instar.

The obtained data in the present work indicate that, Consult caused inhibition effect in all treatments.

\subsection{In adults:}

The haemolymph were collected from the moulted adults females and males, after 7 and 10 days of treated one day and six day old of the $5^{\text {th }}$ nymphal instars with Consult.

The results indicate that, in normal female after 10 days the total protein less than total protein after 7 days where ovarian growth starts from sixth day (including vitellogenin in haemolymph), then after two or three days, the vitellogenin was uptake by developing oocytes, these results was also proved by (Goltzene, 1977) who recorded that in locusts, vitellogenesis is completed within about 8 days, also (Highnam, 1962) and Elliott and Gillott, 1977) observed that total haemolymph protein decreases during oocytes maturation in grasshoppers.

Also, in the case of normal male, total haemolymph protein after 7 days was high then decrease due to the differentiation of reproductive organs and process of spermatogenesis in S. gregaria testes.

Also, the result indicated that Consult caused inhibition of total haemolymph protein in adults of one day old treated $5^{\text {th }}$ nymphal instars of $S$. gregaria, but total haemolymph protein in adults of six day old treatment increase then decreased less than control.

Total haemolymph protein, in high concentration of Consult (100 ppm) of one day old treatment and in all concentrations of six day old treatment of adults after 10 days more than total haemolymph protein after 7 days and this rather than control.

The reduction and stimulation of the protein levels may be due to the destructive effect of the tested compounds on some of the cerebral neurosecretory cells of the brain of the treated nymphs. While, in the adults these cells in the brain are responsible for the secretion of the proteins. This result was also proved by Lusis (1963) who recorded that, the neurosecretion from the pars intercerebralis of the brain affected the synthesis of proteins in the fat body. Thus, insufficient stimulation of neurosecretarory activity would lead to protein deficiency and reduced the amount of the protein, which required for oocytes development, and absorbed from the haemolymph.

The findings agree with Steel and Hall (1985), they found that the protein content levels in the haemolymph of the treated nymphs were less than in the control nymphs, when treated the last nymphal instar of Schistocerca gregaria by benzoyl-phenyl urea (S-71624). Also, the reduction of protein level in the haemolymph of the treated females and males of the last nymphal instars of $S$. gregaria was recorded by Badawy \& ElGammal 2000 and Bakr et al.2007 ) when treated the $5^{\text {th }}$ female and male nymphal instars by benzoyl-phenyl urea (S-71624).

The reduction of the concentrations of juvenile hormone, ecdysteroids and protein in the haemolymph of the last two nymphal instars of Locusta migratoria were also recorded by Baehr et al. (1979) when studied the effect of juvenile hormone levels, and ecdysteroids on protein in the haemolymph of the last two nymphal instars. Eid et al. (1982) reported that, when newly moulted $4^{\text {th }}$ instar nymphs of Schistocerca gregaria were treated in laboratory topically with precocoene II at $20 \mu \mathrm{g} /$ locust or cycloheximide at $10 \mu \mathrm{g} / \mathrm{locust}$. The effects of precocoene II might be attributed to the lack of release of juvenile hormone, whereas those of cycloheximide suggested the inhibition of protein.El-Gammal et al. (1993) found that, IKI increased haemolymph protein concentration and protein bands in 8-day after application of IKI against one day old of $5^{\text {th }}$ nymphal instar of S. gregaria.

\section{Total protein in ovary and testis:}

The present study indicated that the effect of Consult on ovary and testis after 10 days of adult, which produced from 
treated one day and six day old of the $5^{\text {th }}$ nymphal instar of $S$. gregaria with different concentrations of Consult (CSI) .

The results showed that total protein in ovary and testis reduced in all treatments and this reduction of total protein increased with the increasing of Consult concentrations. Total protein in normal ovary and testis after the tenth day of adult increased but in haemolymph decreased.

Generally, the initial reduction of the protein levels in the studied tissue of the treated adult than normal may reflect a reduction in the capacity of protein synthesis or uptake or the reduction in ability of oocytes to absorb proteins of haemolymph.

The sterility effect of the IGRs on the adults, which treated as a nymphal stage may be due to the effect of the selected compounds on the $\mathrm{JH}$ titer, ecdysteroid synthesis. Sterility adult females may be attributed to the lack of the haemolymph protein, which resulted in the inhibition of oogenesis and ovarian development.

This explanation agree with other workers as Lusis (1963) who suggested that the oocytes development in Schistocerca gregaria is controlled by the combination of the neurosecretion from the pars intercerebralis of the brain and of the corpus allatum hormone, the first affecting the synthesis of proteins in the fat body, and the second facilitating their transport from haemolymph to the oocytes to be used in yolk formation. Thus, insufficient stimulation of neurosecretory activity would lead to protein deficiency and reduced ability of oocytes to absorb it from the haemolymph. So, the effect of the tested compounds on the different types of the neurosecretion of Schistocerca gregaria leads to sexual immaturation.

The important effect of the corpus allatum was proved by Weed Pfeiffer (1939 and 1945) who found that, in Melanoplus differentialis the removal of corpora allata inhibited the growth of oocytes when they reached the stage of yolk deposition, while the size of the fat body greatly increased; this suggested that the corpora allata hormone facilitated the mobilistation of the stored fat body proteins and its utilization for egg yolk formation. Similar conclusions were reached by Joly (1955 and 1960) in her work on Locusta, the removal of the ovaries prevents the increase of corpora allata and causes an accumulation of secretion in the system this replaces an early suggestion (Mestscherskaya 1931, Iwanoff and Mestscherskaya 1935) that ovaries may exert a hormonal action.

\section{REFERENCES}

Abbassi, K.; Zineb A. and Ghaout, S. (2003). Biological effects of alkaloids extracted from: Three plants of Moroccan avid areas on the desert locust. J. Physiologica; Entomol.; 28: 232-236.

Alrubeai, H. F. and Gorell, T.A. (1982). Electrophoretic analysis of testicular protein components in developing Tenebrio molitor. Insect Biochm., 12 (2): 171-175.

Badawy, N. S. and El-Gammal, A. M. (2000). The biochemical effects of the antichitin synthesis compound (S-71624) in the haemolymph of the fifth nymphal instar of Schistocerca gregaria (Forskal). Egypt. J Appl. Sci., 15 (9): 279290.

Badawy, N. S. and El-Gammal, A. M. (2000): The biochemical effects of the antichitin synthesis compound (S-71624) in the haemolymph of the fifth nymphal instar of Schistocerca gregaria (Forskal). Egypt. J Appl. Sci., 15 (9): 279290.

Baehr, J. C.; Prochereon, P.; Papillion M. and Dry, F. (1979): Haemolymph levels of juvenile hormone, ecdysteroids and protein during the last two larval instars of Locusta migratoria. J. Insect Physiol., 25: 415-421.

Bakr, R. F. A.; M.S. Hamed and N. A. Abdel-Razik (1984). Ovicidal activity of certain insect growth regulators (IGRs) against Culex pipiens (Diptera: Culicidae). Ain Shams Sci. Bull. 25(B): 349362.

Bakr, R. F. A.; N. A. Abdel-Razik and M. S. Hamed (1984). Larvicidal effect 
of certain insect growth regulators (IGRs) against Culex pipiens (Diptera: Culicidae). Ain Shams Sci. Bull. 25(B): 363-379.

Bakr, R. F. A.; N. M. Abo-Gabal and M. A. Hussein (1989). Insectgrowth regulators: 1. Biological activity of some IGRs against the susceptible and resistant strains of Culex pipiens larvae.11. Pattern of cross resistance of IGRs in carbarylresistant strain. J. of Egypt. Soc. of Parasitology, 19 (2):589-597.

Bakr R. F. A.; Abdel- Fattah H. M. and Mohamed E. K. (2007). Effect of chitin synthesis inhibitor, Lufenuron on the development, haemolymph and antennal sensilla of Schistocerca gregaria (Forskal) (Orthoptera: Acrididae). African J. Biol. Sci. 3(2): 35 - 43.

Bakr R. F. A.; Hussein M A.; Hamouda L. S.; Hassan H.A.; Elsokary Z. F. (2008). Effect of some insecticidal agents on some biological aspects and protein patterns of desert locust, Schistocerca gregaria (Forskal). Egypt. Acad. Soc. Environ. Develop., 9(2): 29-42.

Bakr, R. F.; Ghoneim, K. S.; Al-Dali, A. G.; Tanani, M. A. and Bream, A. S. (2008). Lethal efficacy of the chitin synthesis inhibitorsflufenoxuron (cas101463) and lufenuron (cga184699) on Schistocerca gregaria (orthoptera: acrididae). Egypt.Acad. J. Biolog. Sci. 1(1) 112.

Bradford, M. M. (1976). Rapid and sensitive method for the quantitation of microgram quantities of protein utilizing the principle of protein dye binding. Anal. Biochem., 72: 248-254.

Eassa, Y. E. E.; Hilmy, A. M. and ElDomiati, N. (1971). Electrophoretic pattern of haemolymph proteins of Locusta migratoria Migratorioides. Bull. Soc. ent. Egypt, LV: 1-15.

Eid, M. A.; Salem, M. S.; El-Ibrashy, M. T. and Abdel-Hamid, M. (1982). Effect of precocene II, Cycloheximide and C16-JH on the growth rate and adult morphometrics of Schistocerca gregaria Forsk. Bull. Entomol. Soc. Egypte, Econ. Ser., 1982/ 1983; (13):95-105.

El-Gammal, A. M.; Osman, M. A.; Shaban, O. A. and Badawy, N. S. (1994). The role of anti-chitin synthesis, chlorfluazuron (IKI) on the main metabolites during metamorphosis of Schistocerca gregaria Forsk. Egyption J. Agric. Res., 71 (4): 891-899.

Elliott, R. H. and Gillott, C. (1977). Changes in the protein concentration and volume of the haemolymph in relation to yolk deposition, ovariectomy, allatectomy, and cautery of the median neurosecretory cells in Melanoplus sanguinipes. Can. J. Zool., 55:97-103.

Engelmann, F. (1970). The physiology of insect reproduction. Department of Zoology, California Univ., Los Angeles, Oxfod, Engl. Pergamon, 307pp.

Ghazawi, A. N.; El-Shranoubi, E. D.; ElShazly, m. M. and Abdel-Rahman, A. (2007). Effects of Azadriachtinon mortality and reproductive system of the grasshopper, Heteracris littoralis Rambo. (Orthoptera: Acrididae). J. Orthoptera Res.; 16 (1): 57-65.

Highnam, K. C. (1962). Neurosecretory control of ovarian development in the desert locust. Mem. Soc. Endocrinol, 12: 379-90.

Iwanoff, P. P. and Mestscherskaya, K. A. (1935). Die physiologischen Besonderheiten der geschlechtlich unreifen Insektenovarien und die Zyklischen Veranderungen ihrer Eigenshaftren. Zool. Jb. (Physiol.), 55: 281-348.

Joly, L. (1955). Analyse du fonctionnement des corpora allata Chez la larva de Locusta migratoria L. C. R. Soc. Biol., Paris, 149: 584587.

Joly, L. (1960). Fonctions des Corpora Allata Chez Locusta migratoria (L.). Strasbourg. 
Lusis, O. (1963). The histology and histochemistry of development and resorption in the terminal oocytes of the desert locust, Schistocerca gregaria. Quart J. Micr. Sci., 104:57-68.

Mestscherskaya,

K.

(1931).

Experimentelle Untresuchungen uber die Permeabilitat der wachsenden Oocyten inInsektenovarien. Z. Zellforsch., 13: 109-160.

Mulla, M. S. (1995). The future of insect growth regulators in vector control. J. Am. Mosq. Control. Assoc., 11 (2): 269-73.

Parrella, M. P. and Murphy, B. C. (1998). Insect growth regulators. Growers Talks, 62(2):86-89.

SAS Institute (1988). SAS/STAT User`s Guide, Ver. 6.03. SAS Institute Inc., Cary, North Carolina.

Sorge, D.; Nauen, R.; Range, S. and Hoffmann, K. H. (2000). Regulation of vitellogensis in the fall armyworm, Spodoptera frugiperda (Lepidoptera : Noctuidae). J. Insect Physiol., 46: 969-976.

Steel, J. E. and S. Hall (1985). Trehalose synthesis and glycogenolysis as sites of action for the corpora cardiacum in Periplaneta americana. Insect Biochem., 15:529-536.

Taha and El-Gammal (1990). Morphogenetic effects of nonterpenoid juvenile hormone analogue, S-31183 on, metamorphosis of last nymphal instar of Schistocerca gregaria. Egyptian J. Appl. Sci., 5: 75-81.

Weed P. I. (1939). Experimental study of the function of the corpora allata in the grasshopper, Melanoplus differentialis. J. exp. Zool., 82: 439461.

Weed P. I. (1945). Effect of the corpora allata on the metablolism of adult female of grasshopper. J. exp. Zool., 99: 183-233.

\section{ARABIC SUMMARY}

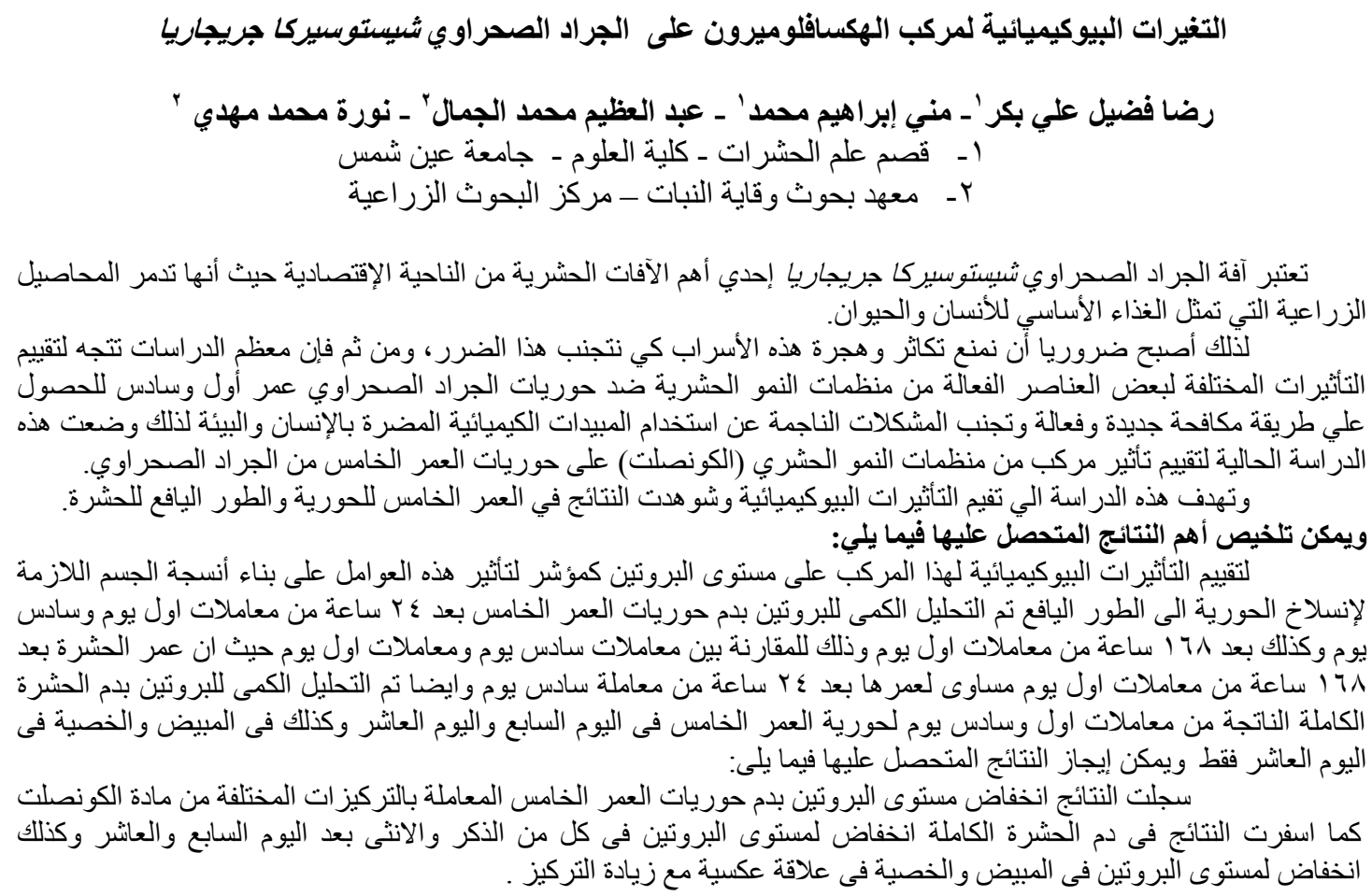

